Original Article

\title{
ISOLATION, CHARACTERIZATION AND VALIDATION OF HPLC METHOD FOR QUANTIFICATION OF BIS-[10-(2-METHYL-4H-3-THIA-4,9-DIAZABENZO[F]AZULENE)]-1,4- PIPERAZINE IN AN ANTI-PSYCHOTIC DRUG SUBSTANCE, OLANZAPINE
}

\author{
SURESH BABU BODEMPUDI', RAVI CHANDRA BABU RUPAKULA*, KONDA S REDDY, MAHESH REDDY GHANTA \\ GITAM University, Visakhapatnam, India, and Dr. Konda's Life Sciences, Hyderabad \\ Email: rrcbabu7@yahoo.in
}

Received: 25 Jan 2018, Revised and Accepted: 15 Apr 2018

\begin{abstract}
Objective: The main objective of present study was to Isolate, characterize and validate a reverse phase high performance liquid chromatographic method was validated for quantification of bis-[10-(2-methyl-4H-3-thia-4,9-diazabenzo[f]azulene)]-1,4-piperazine in 0lanzapine drug substance; it decreases the mental disorders in human body. The method is specific, rapid, precise and accurate for the separation and determination of bis-[10(2-methyl-4H-3-thia-4,9-diazabenzo[f]azulene)]-1,4-piperazine in Olanzapine drug substance form.
\end{abstract}

Methods: The bis-[10-(2-methyl-4H-3-thia-4,9-diazabenzo[f]azulene)]-1,4-piperazine of Olanzapine was resolved on a Zorbax RX-C 8, 250 mm X $4.6 \mathrm{~mm}, 5$ micron column (L-1) using a mobile phase system containing $0.03 \mathrm{M}$ sodium dodecyl sulphate in water pH $2.5 \mathrm{with} 1 \mathrm{~N}$ sodium hydroxide solution and acetonitrile in the ratio of (Mobile phase A-52:48 v/v) and (Mobile phase B-buffer and Acetonitrile 30:70 v/v) by using the gradient program. The mobile phase was set at a flow rate of $1.5 \mathrm{ml} / \mathrm{min}$ and the volume injected was $20 \mu \mathrm{l}$ for every injection. The detection wavelength was set at $220 \mathrm{~nm}$ and the column temperature was set at $35^{\circ} \mathrm{C}$.

Results: The proposed method was productively applied for the quantitative determination of bis-[10-(2-methyl-4H-3-thia-4,9-diazabenzo [f]azulene)]-1,4-piperazine in Olanzapine drug substance form. The linear regression analysis data for calibration plots showed a good linear relationship over a concentration range of 0.025 to $0.903 \mu \mathrm{g} / \mathrm{ml}$ for bis-[10-(2-methyl-4H-3-thia-4,9-diazabenzo[f]azulene)]-1,4-piperazine, 0.081$0.608 \mu \mathrm{g} / \mathrm{ml}$ for Olanzapine. The mean values of the correlation coefficient were 0.999 and 0.999 for bis-[10-(2-methyl-4H-3-thia-4,9diazabenzo[f]azulene)]-1,4-piperazine and Olanzapine. The method was validated as per the ICH guidelines. The detection limit (LOD) was about $0.007 \mu \mathrm{g} / \mathrm{ml}, \quad 0.024 \mu \mathrm{g} / \mathrm{ml}$ and quantitation limit (LOQ) was about $0.024 \mu \mathrm{g} / \mathrm{ml}, 0.081 \mu \mathrm{g} / \mathrm{ml}$ for bis-[10-(2-methyl-4H-3-thia-4,9diazabenzo[f]azulene)]-1,4-piperazine and Olanzapine. The relative standard deviation was found to be $1.64 \%$ and $2.18 \%$ for bis-[10-(2-methyl4H-3-thia-4,9-diazabenzo[f]azulene)]-1,4-piperazine and Olanzapine.

Conclusion: The validated HPLC method and the statistical analysis showed that the method is repeatable and selective for the estimation of the bis-[10-(2-methyl-4H-3-thia-4,9-diazabenzo[f]azulene)]-1,4-piperazine of the Olanzapine drug substance.

Keywords: Bis-[10-(2-methyl-4H-3-thia-4, 9-diazabenzo[f]azulene)]-1, 4-piperazine, Olanzapine, Isolation, Characterization, HPLC, Quantification and Validation

(c) 2018 The Authors. Published by Innovare Academic Sciences Pvt Ltd. This is an open access article under the CC BY license (http://creativecommons.org/licenses/by/4.0/) DOI: http://dx.doi.org/10.22159/ijcpr.2018v10i4.28454

\section{INTRODUCTION}

Olanzapine (2-methyl-4(4-methyl-1-piperazinyl)-10H-thieno [2,3-b] $[1,5]$ benzodiazepine) (fig. 1-C) [1] is a potential antipsychotic agent used in chemotherapy. It has been approved by the FDA, is one of the most commonly used typical antipsychotics, and is also used for treatment of schizophrenia, acute mania in bipolar disorder, agitation associated with schizophrenia, and bipolar disorder [2-3]. There are several high-performance liquid chromatography (HPLC) methods for the determination of OLANZAPINE [4-8]. Hence, an attempt has been made to develop an accurate, rapid, specific and reproducible method for determination of bis-[10-(2-methyl-4H-3-thia-4,9-diazabenzo [f] azulene)]-1,4-piperazine in bulk drug samples of Olanzapine along with method validation as per ICH norms [9]. The stability tests were also performed on drug substances as per ICH norms $[10,11]$. In the present research we describe an isolation, Characterization and validated high performance liquid chromatography (RP-HPLC) method for the separation, determination and quantification of process related impurity of Olanzapine.

\section{MATERIALS AND METHODS}

Instruments

Chromatography was carried out by using Water's Alliance instrument equipped with column oven, UV detector, and the data was processed using a computer program (with Empower-2 software).

\section{Chemicals and reagents}

2-methyl-4H-3-thia-4,9-diazabenzo[f]azulen-10-ylamine hydrochloride, piperazine, 2-methyl-4-(piperazin-1-yl)-5H-benzo[b] thieno[2,3-e] $[1,4]$ diazepine and Olanzapine was obtained from the RandD department of Dr. Konda's life sciences (Hyderabad, India). Merck grade Ammonium acetate, Ammonia, and methanol was purchased from Merck (Mumbai, India). Standard solution of analyte was prepared in the diluent at a concentration of $0.4 \mathrm{mg} / \mathrm{ml}$ of Olanzapine with $99.70 \%$ purity and bis-[10-(2-methyl-4H-3-thia4,9-diazabenzo[f]azulene)]-1,4-piperazine (Dimer with $94.00 \%$ purity) were prepared in the laboratory.

\section{Chromatographic conditions}

The chromatographic conditions were optimized by using a RP stationary phase, Zorbax RX-C8 column $(250 \times 4.0 \mathrm{~mm}, 5 \mu \mathrm{m}$. The gradient mobile phase composition was a mixture of $0.03 \mathrm{M}$ sodium dodecyl sulfate in water $\mathrm{pH} 2.50$ with $1 \mathrm{~N}$ sodium hydroxide solution and methanol (Mobile phase-A 52:48 v/v) and (Mobile phase-B 70:30 $\mathrm{v} / \mathrm{v}$ ), which was pumped at a flow rate of $1.5 \mathrm{ml} / \mathrm{min}$. The temperature of the column was maintained at $35^{\circ} \mathrm{C}$ and the eluent was monitored at a wavelength of $220 \mathrm{~nm}$. The injection volume was $20 \mu \mathrm{l}$.

The chromatographic parameters, including the retention factor $(\mathrm{k})$, the separation factor $(\alpha)$, and the resolution (Rs) were selected to evaluate the separation of com-pounds. All the chromatographic results were repeated three times. 


\section{Sample preparation}

Standard solutions of Olanzapine $(0.4 \mathrm{mg} / \mathrm{ml})$ and bis-[10-(2methyl-4H-3-thia-4,9-diazabenzo[f]azulene)]-1,4-piperazine $(0.0004 \mathrm{mg} / \mathrm{ml})$ were prepared by dissolving appropriate amount of the substance in mobile phase. The analyte concentration of Olanzapine was fixed as $400 \mu \mathrm{g} / \mathrm{ml}$. Olanzapine solutions spiked with low levels of bis-[10-(2-methyl-4H-3-thia-4,9-diazabenzo [f] azulene)]-1,4-piperazine were prepared by transferring calculated amount of stock solution with pipette into the calculated amount of Olanzapine standard solution, and then the solution was added to volume with mobile phase and mixed well.

\section{Validation of the method}

The specificity of the method is performed by injecting both Olanzapine and bis-[10-(2-methyl-4H-3-thia-4,9-diazabenzo[f] azulene)]-1,4-piperazine individually. The specificity determined by using peak purity, resolution.

The system suitability of the method performed by adding known concentration $(0.4 \mu \mathrm{g} / \mathrm{ml})$ of bis-[10-(2-methyl-4H-3-thia-4,9diazabenzo[f]azulene)]-1,4-piperazine to Olanzapine. The system suitability is confirmed by using resolution, tailing factor, Tangent.

Method reproducibility was determined by measuring repeatability and intermediate precision of retention times and peak areas for each bis-[10-(2-methyl-4H-3-thia-4,9-diazabenzo[f]azulene)]-1,4piperazine and Olanzapine. The repeatability of the method was determined by analyzing six replicate injections containing Olanzapine $(400 \mu \mathrm{g} / \mathrm{ml})$ spiked with bis-[10-(2-methyl-4H-3-thia4,9-diazabenzo[f]azulene)]-1,4-piperazine $(0.1 \%, 0.4 \mu \mathrm{g} / \mathrm{ml})$. The Method precision and intermediate precision was determined over 2 $\mathrm{d}$ by performing six successive injections $(n=6)$ each day and performed with different system, different analyst and with different column by using six injections $(n=6)$.

The limit of detection (LOD) and limit of Quantitation (LOQ) for bis[10-(2-methyl-4H-3-thia-4,9-diazabenzo[f]azulene)]-1,4-piperazine was achieved by injecting a series of dilute solutions of by using standard deviation slope method (ICH Q2 (R1)). The LOQ level precision of the developed HPLC method for bis-[10-(2-methyl-4H3-thia-4,9-diazabenzo[f]azulene)]-1,4-piperazine was checked by analyzing six solutions of bis-[10-(2-methyl-4H-3-thia-4,9- diazabenzo[f]azulene)]-1,4-piperazine prepared at LOQ level and calculating the percentage relative standard deviation of area.

Detector response linearity was assessed by preparing eight calibration sample solutions of bis-[10-(2-methyl-4H-3-thia-4,9diazabenzo[f]azulene)]-1,4-piperazine covering from $0.025 \mu \mathrm{g} / \mathrm{ml}$ (LOQ) to $0.903 \mu \mathrm{g} / \mathrm{ml}(0.025,0.181,0.301,0.602,0.723$, and 0.903 $\mu \mathrm{g} / \mathrm{ml}$ ) in mobile phase. The regression curve was obtained by plotting peak area versus concentrations, using the least square method. The percentage relative standard deviation of the slope and $y$-intercept of the calibration curve was calculated.

The accuracy of method was carried out by injecting known concentration of bis-[10-(2-methyl-4H-3-thia-4,9-diazabenzo [f] azulene)]-1,4-piperazine to the Olanzapine. The accuracy was calculated in terms of recovery (\%). The study was carried out in triplicate at covering from LOQ to $0.903 \mu \mathrm{g} / \mathrm{ml}$ (LOQ, 0.301, 0.602 and $0.903 \mu \mathrm{g} / \mathrm{ml}$ ) in mobile phase. The recovery of bis-[10-(2-methyl-4H-3-thia-4,9diazabenzo[f]azulene)]-1,4-piperazine was calculated.

To determine robustness of the method, flow rate was changed at the pace of 0.2 units from 1.3 to $1.7 \mathrm{ml} / \mathrm{min}$. The effect of change in the percent Buffer and Methanol $( \pm 10 \%)$, and column temperature at $30^{\circ} \mathrm{C}$ and $40^{\circ} \mathrm{C}$ instead of $35^{\circ} \mathrm{C}$ were studied, and the other chromatographic conditions were held constant as stated previously.

The solution stability of Olanzapine at analyte concentration was studied by keeping the solution in tightly capped volumetric flask at room temperature on a laboratory bench for $48 \mathrm{~h}$. The content of bis-[10(2-methyl-4H-3-thia-4,9-diazabenzo[f]azulene)]-1,4-piperazine was checked at $6 \mathrm{~h}$ interval up to the study period. Mobile phase stability was carried out by evaluating the content of bis-[10-(2-methyl-4H-3-thia-4,9diazabenzo[f]azulene)]-1,4-piperazine in Olanzapine sample solutions prepared freshly at $6 \mathrm{~h}$ interval of $48 \mathrm{~h}$. The same mobile phase was used during the study period.

\section{Synthesis of bis-[10-(2-methyl-4H-3-thia-4,9-diazabenzo[f] azulene)]-1,4-piperazine}

Olanzapine was synthesized in the laboratory by a known pathway as per the literature which involved the reaction of 2-methyl-4H-3thia-4,9-diazabenzo[f]azulen-10-ylamine hydrochloride $\mathrm{A}$ with piperazine to give $B$, which on further methylation with dimethyl sulfate yielded olanzapine $\mathrm{C}$.

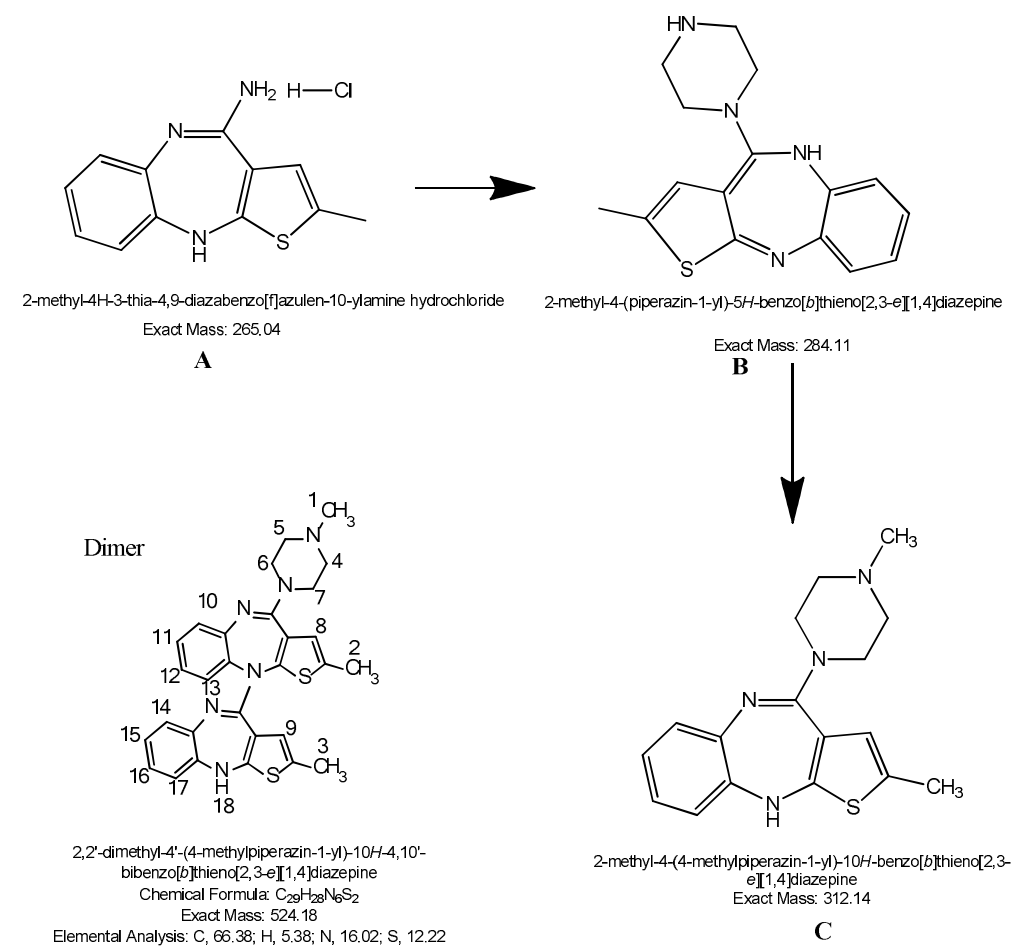

Fig. 1: Synthetic route of olanzapine 


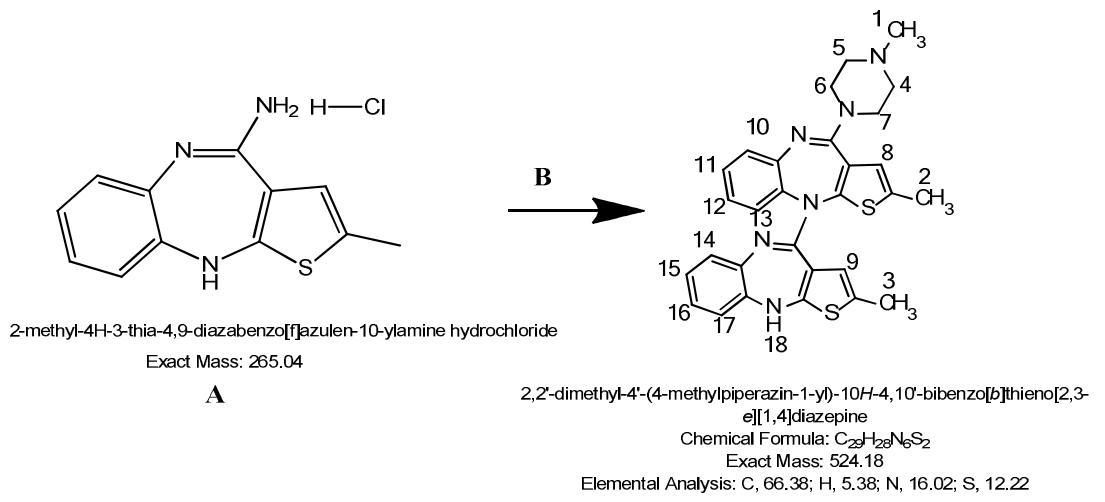

Fig. 2: Synthetic route of dimer impurity

Any residual of A present in the reaction reacts with compound B to give bis-[10-(2-methyl-4H-3-thia-4,9-diazabenzo[f]azulene)]-1,4piperazine (Dimer impurity). This impurity is formed only in trace quantities.

\section{Bis-[10-(2-methyl-4H-3-thia-4,9-diazabenzo[f]azulene)]-1,4- piperazine}

A mixture of 2-methyl-10-piperazin-1-yl-4H-3-thia-4,9-diazabenzo [f]azulene $(3,10.0 \mathrm{~g}, 0.034 \mathrm{~mol})$, dimethyl sulfoxide $(10 \mathrm{ml})$, toluene $(40 \mathrm{ml})$ and 2-methyl-4H-3-thia-4,9-diazabenzo[f]azulen-10ylamine hydrochloride $(2,9.0 \mathrm{~g}, 0.034 \mathrm{~mol})$ was heated to reflux. Triethylamine $(20 \mathrm{ml})$ was added in three equal portions to the reaction mixture at reflux temperature and the reaction mass was stirred for reaction completion. The reaction mixture was cooled to $35^{\circ} \mathrm{C}$ and the undissolved material was filtered off. The filtrate was concentrated under reduced pressure. To the residue, water $(50 \mathrm{ml})$ was added and the mixture was stirred for solid separation. The isolated solid was filtered, washed with aqueous methanol and dried at $60{ }^{\circ} \mathrm{C}$ to a constant weight to yielded require compound (Yield: $10.1 \mathrm{~g}$, HPLC purity: $94.0 \%$ ).

\section{Validation results of the method}

The HPLC condition of the final method was evaluated for its specificity, LOD, LOQ, linearity, accuracy, precision, robustness and stability. The specificity of the method was determined by using peak purity. The specificity results are given in table 1 .

Table 1: Specificity

\begin{tabular}{llll}
\hline Compound & Purity angle & Purity threshold & Peak purity \\
\hline Dimer & 0.043 & 1.086 & Pass \\
Olanzapine & 0.273 & 1.002 & Pass \\
\hline
\end{tabular}

The limit of detection and limit of quantification of bis-[10-(2methyl-4H-3-thia-4,9-diazabenzo[f]azulene)]-1,4-piperazine was found to be $0.007 \mu \mathrm{g} / \mathrm{ml}$ and $0.024 \mu \mathrm{g} / \mathrm{ml}$, respectively. Calculated the LOD and LOQ by using signal to noise ratio method. The LOD and LOQ values for Olanzapine were $0.0024 \mu \mathrm{g}$ and $0.081 \mu \mathrm{g} / \mathrm{ml}$. Method precision for bis-[10-(2-methyl-4H-3thia-4,9-diazabenzo [f]azulene)]-1,4-piperazine at $0.4 \mu \mathrm{g} / \mathrm{ml}$ was less than $2.0 \%$ RSD. The resolutions between bis-[10-(2-methyl-4H3-thia-4,9-diazabenzo[f]azulene)]-1,4-piperazine and Olanzapine were found more than 2.0. Therefore, this method had adequate sensitivity for the detection and estimation of bis-[10-(2-methyl4H-3-thia-4,9-diazabenzo[f]azulene)]-1,4-piperazine in Olanzapine.
Good linearity of (bis-[10-(2-methyl-4H-3-thia-4,9-diazabenzo [f] azulene)]-1,4-piperazine was evaluated over six levels of bis-[10-(2methyl-4H-3-thia-4,9-diazabenzo[f]azulene)]-1,4-piperazine solutions from $0.025 \mu \mathrm{g} / \mathrm{ml}$ to $0.903 \mu \mathrm{g} / \mathrm{ml}$, with the linear regression equation $\mathrm{y}=$ $\mathrm{mx}+\mathrm{c}$, where $\mathrm{x}$ is the concentration in $\mu \mathrm{g} / \mathrm{ml}$, and $\mathrm{y}$ is the corresponding peak area of bis-[10-(2-methyl-4H-3-thia-4,9-diazabenzo[f]azulene)]1,4-piperazine in $\mathrm{mV} / \mathrm{s}$. We observed linear results with respect to concentration for bis-[10-(2-methyl-4H-3-thia-4,9-diazabenzo[f] azulene)]-1,4-piperazine. The correlation coefficient value is more than 0.999 . The linearity results of bis-[10-(2-methyl-4H-3-thia-4,9diazabenzo[f]azulene)]-1,4-piperazine and Olanzapine are given in table 2 and in table 3 . The linearity graph was shown in fig. 3 and in fig. 4 correspondingly.

Table 2: Linearity of dimer impurity

\begin{tabular}{lll}
\hline S. No. & Concentration $(\boldsymbol{\mu g} / \mathbf{m l})$ & Dimer Imp peak $\left.\mathbf{~}^{\mathbf{n}}=\mathbf{6}\right)$ \\
\hline 1 & 0.025 & 1319 \\
2 & 0.181 & 14793 \\
3 & 0.301 & 24496 \\
4 & 0.602 & 48831 \\
5 & 0.723 & 59115 \\
6 & 0.903 & 73965 \\
Correlation coefficient & 0.9999 \\
Slope & & 82323.4940 \\
Y-intercept & & -440.4315 \\
$\mathrm{r}^{2}$ & & 0.9999 \\
\hline
\end{tabular}

*Mean of six determinations 
Table 3: Linearity of olanzapine

\begin{tabular}{lll}
\hline S. No. & Concentration $(\boldsymbol{\mu g} / \mathbf{m l})$ & Olanzapine peak* $(\mathbf{n}=\mathbf{6})$ \\
\hline 1 & 0.081 & 2271 \\
2 & 0.122 & 4623 \\
3 & 0.203 & 7476 \\
4 & 0.405 & 14900 \\
5 & 0.486 & 18506 \\
6 & 0.608 & 22958 \\
Correlation coefficient & 0.9994 \\
Slope & & 38604.6412 \\
Y-intercept & & -463.1609 \\
$\mathrm{r}^{2}$ & & 0.9987 \\
\hline
\end{tabular}

*Mean of six determinations

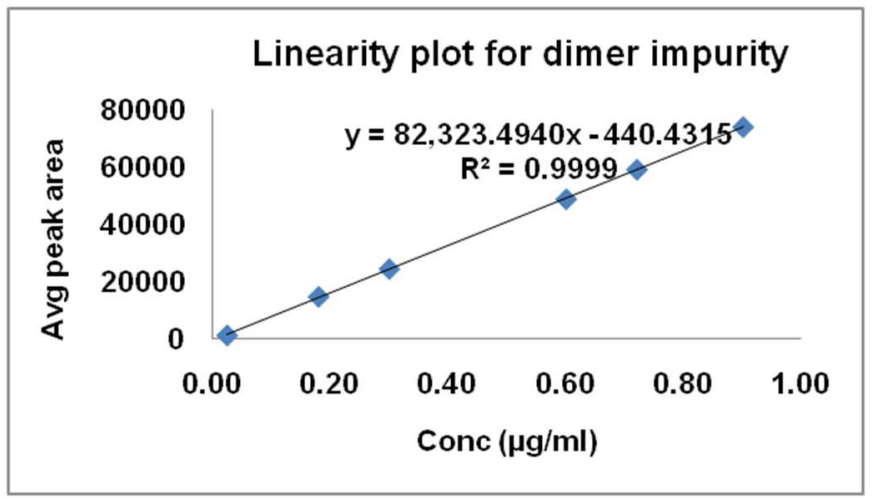

Fig. 3: Linearity plot for dimer impurity

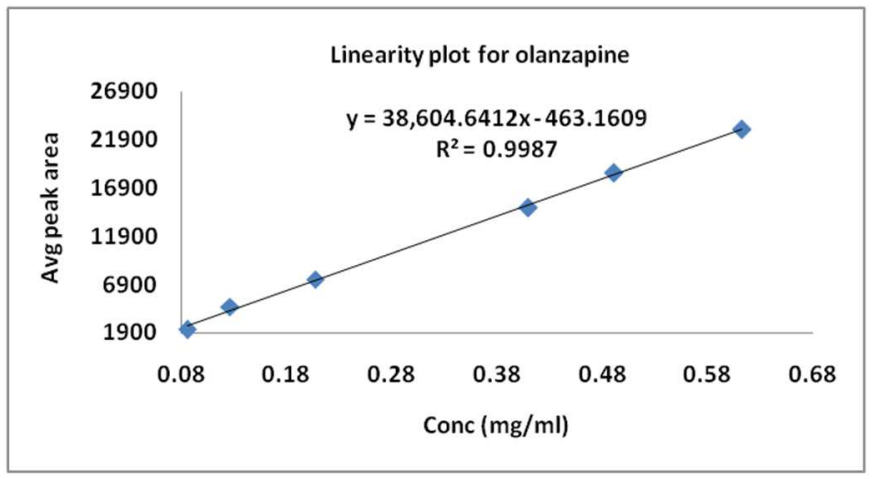

Fig. 4: Linearity plot for olanzapine

The standard addition and recovery experiments were conducted for bis-[10-(2-methyl-4H-3-thia-4,9-diazabenzo[f]azulene)]-1,4-piperazine in bulk samples in triplicate at $0.301 \mu \mathrm{g} / \mathrm{ml}$ to $0.903 \mu \mathrm{g} / \mathrm{ml}(0.301$, 0.602 and $0.903 \mu \mathrm{g} / \mathrm{ml}$ ). The accuracy was in terms of recovery (\%). The recovery was calculated by back calculated concentration at each level in each preparation. The recovery is not less than $99.0 \%$ and not more than $102.0 \%$. The recovery results are given in table 4 .

The repeatability and intermediate precision were expressed as relative standard deviation (RSD). For this study, solution of
Olanzapine $(400 \mu \mathrm{g} / \mathrm{ml})$ spiked with bis-[10-(2-methyl-4H-3-thia4,9-diazabenzo[f]azulene)]-1,4-piperazine $(0.1 \%, 0.4 \mu \mathrm{g} / \mathrm{ml})$ was analyzed in six injections to establish repeatability. RSD values were better than $0.5 \%$ for the retention times of both the bis-[10-(2methyl-4H-3-thia-4,9-diazabenzo[f]azulene)]-1,4-piperazine and Olanzapine. In the intermediate precision study results shown that RSD values were in same order of magnitude than those obtained for repeatability studies were captured in table 5 . All these values indicated that the method was precise.

Table 4: Accuracy

\begin{tabular}{lll}
\hline Added amount $(\mu \mathrm{g} / \mathrm{ml})$ & Recovery $(\%)$ & $* \%$ RSD (n = 3) \\
\hline 0.301 & 99.33 & 1.12 \\
0.602 & 99.28 & 0.68 \\
0.903 & 99.92 & 0.72 \\
\hline
\end{tabular}

*Mean of three determinations at each concentration 
Table 5: Ruggedness

\begin{tabular}{ll}
\hline Name of the interval & * \% RSD (n = 6) \\
\hline Day-1 & 0.2 \\
Day-2 & 0.4 \\
Day-3 & 0.3 \\
Different system & 0.2 \\
Different column & 0.2 \\
Different analyst & 0.3 \\
\hline
\end{tabular}

*Mean of six determinations

As per ICH, the method robustness studies were demonstrated by adjusting flow rate, column temperature and mobile phase composition variations. The chromatographic resolution of Olanzapine and bis-[10-(2-methyl-4H-3-thia-4, 9-diazabenzo[f] azulene)]-1,4piperazine was more than 2.0 under all separation conditions. The robustness results were captured in table 6 .

Table 6: Robustness

\begin{tabular}{|c|c|c|c|}
\hline \multirow[t]{2}{*}{ Description } & \multirow[t]{2}{*}{ USP Tailing } & USP & USP \\
\hline & & Tangent & Resolution \\
\hline Column flow: $1.3 \mathrm{ml} / \mathrm{min}$ & 1.0 & 8252 & 8.4 \\
\hline Column flow: $1.7 \mathrm{ml} / \mathrm{min}$ & 1.1 & 9345 & 8.1 \\
\hline Column Temp: $30^{\circ} \mathrm{C}$ & 1.1 & 8536 & 8.3 \\
\hline Column Temp: $40^{\circ} \mathrm{C}$ & 1.0 & 9285 & 8.2 \\
\hline Organic ratio: $110 \%$ & 1.0 & 9136 & 8.0 \\
\hline Organic ratio: $90 \%$ & 1.1 & 8645 & 8.5 \\
\hline
\end{tabular}

The stability of the solution and mobile phase used in this method was tested over a long time. No significance change in bis-[10-(2methyl-4H-3-thia-4,9-diazabenzo[f]azulene)]-1,4-piperazine content was observed in Olanzapine sample during solution stability and mobile phase stability experiments, and the RSD values were less than $2.0 \%$ for bis-[10-(2-methyl-4H-3-thia-4,9-diazabenzo[f] azulene)]-1,4-piperazine peak area. No unknown peak was observed in above stability conditions. Hence, the Olanzapine sample solution and the mobile phase were stable for up to $48 \mathrm{~h}$ and the results were captured in table 7.

Table 7: Solution stability

\begin{tabular}{llll}
\hline S. No. & Time interval & Dimer peak *area (n=7) & 0lanzapine peak *area (n=7) \\
\hline 1 & Initial & 16252 & 72125 \\
2 & After 6 H & 16528 & 72326 \\
3 & After 12 H & 16345 & 72818 \\
4 & After 18 H & 15986 & 73025 \\
5 & After 24 H & 16351 & 72965 \\
6 & After 36 H & 15832 & 73124 \\
7 & After 48 H & 15962 & 72969 \\
Average & & 16278 & 72574 \\
STDEV & & 225.7792 & 418.7446 \\
\% RSD & & 1.39 & 0.58 \\
\hline
\end{tabular}

*Mean of seven determinations

\section{Batch analysis}

By using this method we can analyzed and quantify bis-[10-(2-methyl4H-3-thia-4,9-diazabenzo[f]azulene)]-1,4-piperazine in Olanzapine in manufacturing batches and $\mathrm{R}$ and $\mathrm{D}$ samples. We get repeatable results in all samples at Quality control department and captured in table 8.

Table 8: Batch analysis

\begin{tabular}{llll}
\hline S. No. & Batch No & Dimer content* $\mathbf{\%} \mathbf{w} / \mathbf{w})$ & Average* $\mathbf{\%} \mathbf{w} / \mathbf{w})$ \\
\hline 1 & OLP/PT001 Pre-01 & 0.01 & 0.01 \\
2 & OLP/PT001 Pre-02 & 0.01 & Not detected \\
3 & OLP/PT002 Pre-01 & Not detected & Not detected \\
4 & OLP/PT002 Pre-02 & Not detected & \\
5 & OLP/RD001 Pre-01 & Not detected & 0.01 \\
6 & OLP/RD001 Pre-02 & Not detected & \\
7 & OLP/RD002 Pre-01 & 0.01 & \\
8 & OLP/RD002 Pre-02 & 0.01 & \\
\hline
\end{tabular}

*Mean of two determinations 


\section{Characterization}

Bis-[10-(2-methyl-4H-3-thia-4,9-diazabenzo[f]azulene)]-1,4-piperazine impurity was characterized by Mass Spectrometry to identify the mass of the impurity. The structural elucidation was performed with the help of NMR spectroscopic technique.

\section{Mass spectrometry (LC-MS) studies}

Quattro Micro ${ }^{\mathrm{TM}}$ API mass spectrophotometer (Waters-Micro mass, Manchester, UK), was used to perform Mass Spectral (MS) analysis using electron spray ionization at a voltage of $4.0 \mathrm{KV}$ at a desolvation gas temperature of $100{ }^{\circ} \mathrm{C}$ and a source temperature of $400{ }^{\circ} \mathrm{C}$. The desolvation gas flow was fixed at $450 \mathrm{l} / \mathrm{h}$.

Mass spectral data identified the structure of bis-[10-(2-methyl-4H3-thia-4,9-diazabenzo[f]azulene)]-1,4-piperazine, which was reported in fig. 1A. A $[\mathrm{M}+\mathrm{H}]^{+}$molecular ion peak was identified in positive ionization mode at $\mathrm{m} / \mathrm{z} 525.4$ corresponding to bis-[10-(2methyl-4H-3-thia-4,9-diazabenzo[f]azulene)]-1,4-piperazine captured in fig. 5 .

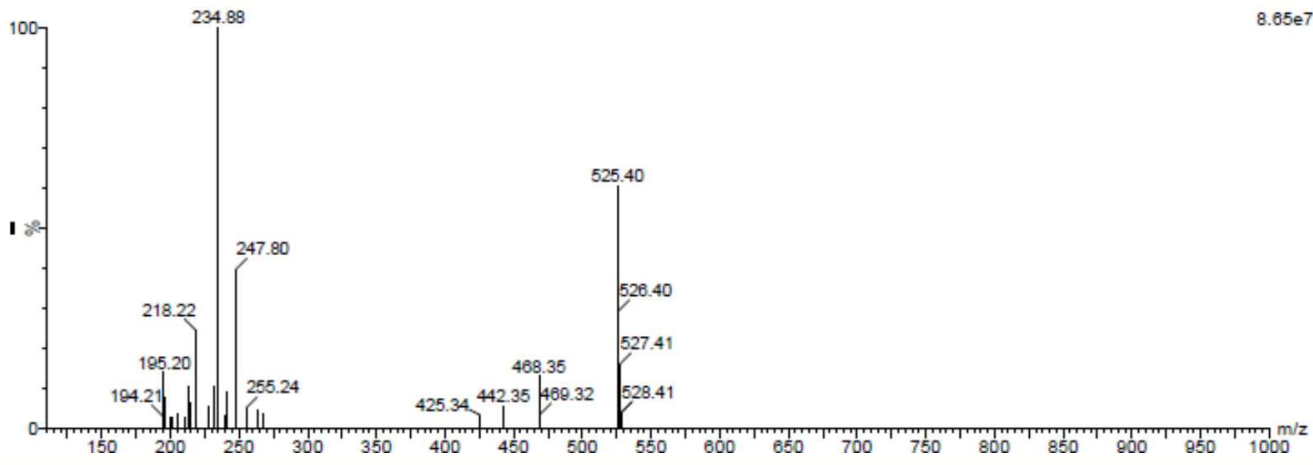

Fig. 5: Mass spectrum of dimer impurity

\section{NMR spectroscopic studies}

Proton NMR experiments were performed using $300 \mathrm{MHz}$ FT-NMR spectrometer (Bruker, BioSpin Corporation, Billerica, MA, USA) in $\mathrm{CDCl}_{3}$ at $25{ }^{\circ} \mathrm{C}$ temperature. The chemical shifts of protons were reported on the $\delta$ scale in ppm relative to TMS and $\mathrm{CDCl}_{3}$ respectively. The ${ }^{1} \mathrm{H}$ NMR spectrum of bis-[10-(2-methyl-4H-3-thia-4,9- diazabenzo[f]azulene)]-1,4-piperazine fig. 6, exhibits a characteristic methylene proton $(\mathrm{s}-6 \mathrm{H})$ chemical shift at $2.2-2.3$, characteristic $\mathrm{CH}_{2}$ proton $(\mathrm{m}-8 \mathrm{H})$ chemical shift $3.2-3.5$, characteristic aromatic proton $(\mathrm{s}-2 \mathrm{H})$ chemical shift at 6.4 , characteristic aromatic proton $(\mathrm{m}-8 \mathrm{H})$ chemical shift at 6.7-6.9 and characteristic NH proton (s-2H) chemical shift at 7.7. The NMR data for the bis-[10-(2-methyl-4H-3-thia-4,9diazabenzo[f]azulene)]-1,4-piperazine was given in table 9.

Table 9: NMR interpretation

\begin{tabular}{lll}
\hline Carbon No & Multiplicity & 1H NMR (ppm) \\
\hline CH3- $(6 \mathrm{H})$ & $\mathrm{s}$ & $2.2-2.3$ \\
$\mathrm{CH} 2-(8 \mathrm{H})$ & $\mathrm{m}$ & $3.2-3.5$ \\
$\mathrm{Ar}-\mathrm{H}-(2 \mathrm{H})$ & $\mathrm{s}$ & 6.4 \\
$\mathrm{Ar}-\mathrm{H}-(8 \mathrm{H})$ & $\mathrm{m}$ & $6.7-6.9$ \\
$\mathrm{NH}-(2 \mathrm{H})$ & $\mathrm{s}$ & 7.7 \\
\hline
\end{tabular}

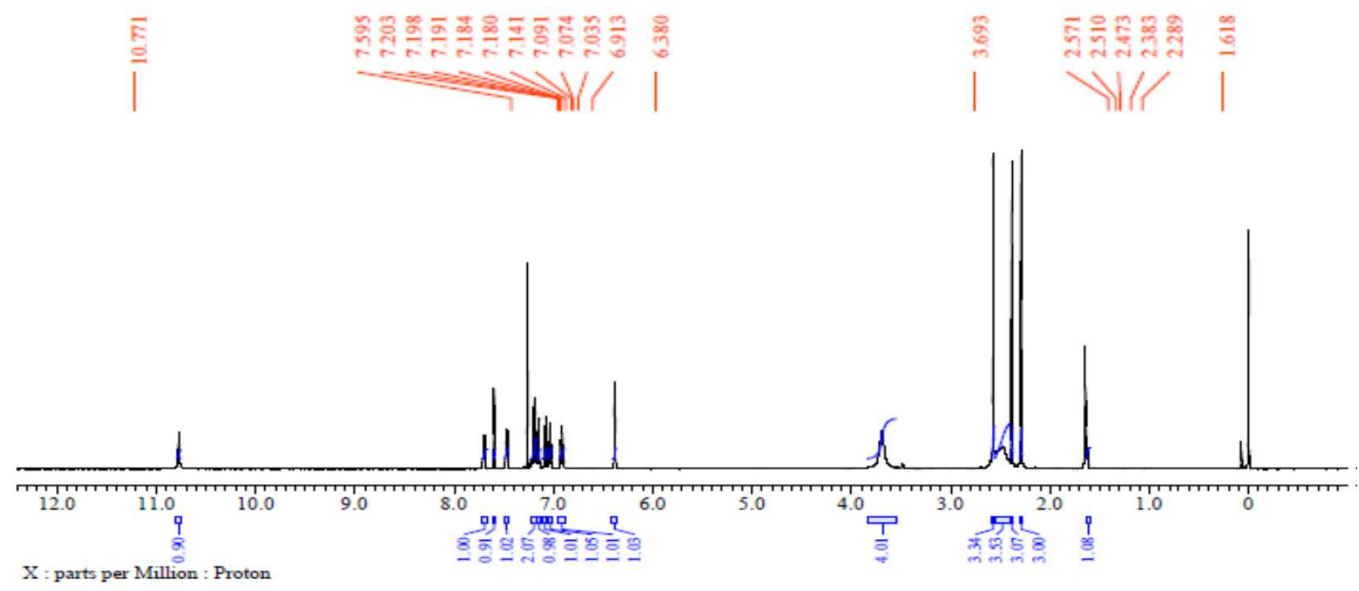

Fig. 6: NMR spectrum of dimer impurity, $C$ H N Analysis Calculated. for $\mathrm{C}_{28} \mathrm{H}_{26} \mathrm{~N}_{6} \mathrm{~S}_{2}: \mathrm{C}: 65.85 ; \mathrm{H}$ : 5.13; N: 16.46 \%: Found: $\mathrm{C}, 65.82 ; \mathrm{H}, 5.21$; $\mathrm{N}, 16.35 \%$

\section{CONCLUSION}

In this study bis-[10-(2-methyl-4H-3-thia-4,9-diazabenzo[f]azulene)]1,4-piperazine impurity was Isolated, characterized and validated by spectroscopic and chromatographic methods and identified by using LCMS technique. Proposed structures of this impurity was confirmed by structural elucidation by using NMR techniques. The HPLC method was validated as per ICH guidelines. This method was found to be simple, 
sensitive, and selective. The method after being completely validated showed satisfactory data for all the method validation parameters, method validation study showed that the method is specific, linear, accurate, easily reproducible and can be used for the determination of bis-[10-(2-methyl-4H-3-thia-4,9-diazabenzo[f]azulene)]-1,4-piperazine in Olanzapine drug substance form.

\section{ACKNOWLEDGEMENT}

The authors wish to state their thanks to the organization of $\mathrm{Dr}$. Konda's life sciences, Hyderabad, India for providing the samples, Brundavan laboratories private limited, Hyderabad, India for providing the research facilities and Gitam University, Visakhapatnam, India for providing the technical support.

\section{AUTHORS CONTRIBUTIONS}

All the author have contributed equally

\section{CONFLICT OF INTERESTS}

Declared none

\section{REFERENCES}

1. Neil MJO. Ed. by the Merck Index-An Encyclopedia of Chemicals, Drugs and Biological; Merck and Co. Inc; 2006.

2. Sweetman SC. Ed. by Martindale, the Complete Drug Reference; Pharmaceutical Press; 2007.

3. Keamey BP, Flherty JF, Shah J. Olanzapine: clinical pharmacology and pharmacokinetics. Clin Pharmacokinet 2004;43:595-612.
4. MA Raggi, G Casamenti, R Mandrioli, G Izzo, E Kenndler. Quantitation of olanzapine in tablets by HPLC, CZE, derivative spectrometry and linear voltammetry. J Pharm Biomed Anal 2000;23:973-81.

5. LJ Dusci, LP Hackett, LM Fellows, KF Ilett. Determination of olanzapine in plasma by high-performance liquid chromatography using ultraviolet absorbance detection. J Chromatogr B 2002;773:191-7.

6. DW Boulton, JS Markowitz, CL Vane. A high-performance liquid chromatography assay with ultraviolet detection for olanzapine in human plasma and urine. J Chromatogr B 2001;759:319-23.

7. JT Catlow, RD Barton, M Clemens, TA Gillespie, M Goodwin, SP Swanson. Analysis of olanzapine in human plasma utilizing reversed-phase high-performance liquid chromatography with electrochemical detection. J Chromatogr B 1995;668:85-90.

8. CS Torre, MA Martinez, E Almarza. Several psychiatric drugs in whole blood using capillary gas-liquid chromatography with nitrogen phosphorus detection: comparison of two solid phase extraction procedures. Forensic Sci Int 2005;155:193-204.

9. Geneva: IFPMA. International Conference on Harmonization. Guidance on validation of analytical procedure: Text and methodology. ICH-Q2(R1); 2005.

10. Stability ICH. "Testing of New Drug Substances and Products Q1A (R2)," International Conference on Har-monization, IFPMA, Geneva; 2003.

11. ICH Photo Stability, "Testing of New Drug Substances and Products Q1b," International Conference on Harmo-nization, IFPMA, Geneva; 1996. 